\title{
Arqueologia de um discurso amoroso: as cartas de amor de Monteiro Lobato \\ Emerson Tin
}

\section{Introdução}

Houve tempo em que o namoro era, o mais das vezes, por escrito. Mário Sette (1886-1950), escritor pernambucano, soube registrar muito bem, em suas memórias, o que era namorar no começo do século XX:

Já que não podíamos nos expandir verbalmente, tivemos que arranjar um jeito de estabelecer uma correspondência escrita. [...] Cartas de namorados de princípio do século... Transbordamentos de corações em juras, promessas, arengas, reconciliações, sonhos, castelos... Para que esconder essas "fraquezas" românticas quando há filhos e netos denunciantes de que fomos bons pagadores de nossas promissórias de amor? (SETTE, 1980, 71, 72)

José Bento Monteiro Lobato (1882-1948) e Maria da Pureza Gouvêa Natividade (1885-1959) eram desse tempo, e a maioria das cartas escritas pelo jovem bacharel à sua jovem noiva, celebrizada pelo diminutivo carinhoso de Purezinha, foi publicada em 1969 pela Editora Brasiliense no volume intitulado Cartas de Amor, organizado por Cordélia Fontainha Seta (1929-), uma amiga da família e antiga correspondente de Lobato. Em seu prefácio, a organizadora afirma de modo categórico:

pela primeira vez terá o leitor a oportunidade de ler as cartas de Lobato exatamente como ele as escreveu, sem que nenhuma revisão fosse feita, quanto ao seu modo todo pessoal de acentuar ou não as palavras; do mesmo modo conservei a pontuação [...] Recebi instruções para que conservasse até mesmo os erros, propriamente ditos, de ortografia, de concordância e de pontuação, para que fosse oferecido ao público todo o sabor destas liberdades que nos permitimos quando não escrevemos para a crítica ou para o público; liberdades que nos permitimos quando escrevemos a quem nos é muito, muito íntimo, e diante de quem não precisamos "posar"; quando escrevemos a quem nos conhece suficientemente bem para saber que nossos desrespeitos à gramática são feitos por despreocupação, pelo prazer de escrever exatamente como se fala, com toda a liberdade - e não por ignorância das regras gramaticais. Uma escrita não de gravata e paletó, mas de pé descalço e short, em momentos a isto adequados. (SETA, 1969, X, XI)

Dois parágrafos antes, contudo, ressalvava a organizadora:

D. Purezinha, já ciente de que, um dia, estas cartas seriam levadas a público, teve o cuidado de, nos originais, obliterar um ou outro nome de pessoas a quem Lobato se referiu com mordacidade; e começou, ela mesma, o trabalho de passar as cartas, de manuscritas para datilografadas. Várias delas já assim encontrei, junto aos originais. (SETA, 1969, X) 
Assim, a rigor, não se poderia afirmar que as cartas foram publicadas "exatamente" como Lobato as escreveu. E realmente podemos afirmar agora que não o foram.

\section{Fragmentos de um discurso amoroso}

A doação pela família de Monteiro Lobato dos manuscritos originais dessa correspondência amorosa, em dezembro de 2001, ao Centro de Documentação Cultural Alexandre Eulálio do Instituto de Estudos da Linguagem da Universidade Estadual de Campinas (CEDAE / IEL / UNICAMP) ${ }^{1}$, junto de outros importantes documentos datiloscritos, exemplares de trabalho (por exemplo, o volume de uma edição do final do século XIX da tradução em prosa para o português de Xavier da Cunha do Orlando Furioso, de Ludovico Ariosto, com diversas anotações de Lobato que reforçam a tese de que o autor pretendia adaptar o épico italiano para o público infantil), fotografias, aquarelas, objetos pessoais -, permitiu a restauração dos textos originais das cartas de amor lobatianas e faz pensar numa possível e futura reedição dessas cartas. Vejamos alguns exemplos que reforçam essa pretensão.

No primeiro desses exemplos, uma longa carta, redigida com tinta vermelha, datada de 30 de setembro de 1906 (a data vem escrita a lápis, talvez pela destinatária, no canto superior esquerdo da primeira página do manuscrito: “30-9-06”), encontramos algumas alterações significativas entre o original manuscrito e a publicação em livro (os trechos alterados vêm em itálico). Lemos no manuscrito depositado no Fundo Monteiro Lobato do CEDAE:

Vejo que, sentada em face do papel encontras difficuldade em achar o que me dizer. Às vezes assalta-me uma supposição horrivel: imagino uma como que suspeita, uma duvida, um receio de que eu não seja o que digo, nem digno de ti, a pairar em tua mente. Mas não é isso, hein, meu benzinho, dize-mo e repete-o, que não é, que nunca será assim. (MLb 3.1.00010)²

Já na edição das Cartas de amor, de 1969, o trecho aparece assim transcrito:

Vejo que, sentada em face do papel, encontras dificuldade em saber o que me dizer. Às vezes assalta-me uma suposição horrivel: imagino uma como que suspeita, uma duvida, a pairar em tua mente de que eu não seja o que digo, nem digno de ti. Mas não é isso, hein, meu benzinho? Dize-mo e repete-o; que não é, que nunca será assim. (LOBATO, 1969, 13)

A inversão das palavras, o torneio original da frase aparece, no livro, passado a limpo. Vejamos mais um outro trecho. No original manuscrito:

Conta-me tua vida ahi, o que fazes, o que pensas, o que sentes; imagina que está a teu lado

Noemia e estás-lhes confidenciando, e escreve quanta cousa vier à tua mente. (MLb 3.1.00010)

Já na edição em livro, o nome da irmã de Purezinha, Noêmia Natividade, desaparece, aparentemente sem qualquer motivo, substituído por uma expressão genérica - "uma amiga": 
Conta-me tua vida ai, o que fazes, o que pensas, o que sentes; imagina que está a teu lado uma amiga e estas-lhe confidenciando, e escreve quanta cousa vier à tua mente. (LOBATO, 1969, 14)

Se nesse trecho podemos imaginar alguma razão para a alteração - por exemplo, a objeção de Noêmia, que talvez se recusasse a aparecer nas cartas exercendo o papel de chaperon -, noutro trecho, a substituição lexical parece não fazer sentido algum. Assim, podemos ler no original manuscrito:

Queres fazer uma cousa? Eu daqui, tu d'ahi, todos os dias, anotaremos num livro as nossas sensações e ideias do dia, que se referirem ao outro. Cada vez que eu for, levo-te o meu e trago o teu; lemo-nos mutua ${ }^{\text {te }}$ e continuaremos a coisa, um no livro do outro. Topas? (MLb 3.1.00010)

Contudo, o que lemos na publicação em livro é diferente do manuscrito:

Queres fazer uma cousa? Eu daqui, tu daí, todos os dias, anotaremos num caderno as nossas sensações e ideias do dia, que se referirem ao outro. Cada vez que eu for, levo-te o meu e trago o teu: lemo-nos mutuamente e continuaremos a coisa, um no caderno do outro. Topas? (LOBATO, 1969,14)

A organizadora preferiu a palavra "caderno" ao termo "livro", constante do original. Por quê? Por que a palavra "livro" não poderia ser mantida no texto? Estaria ela apenas respeitando uma opção de D. Purezinha, que já havia iniciado a datilografação das cartas? Como poderemos saber o que ditou as escolhas da organizadora?

Por fim, a última intervenção nessa carta diz respeito a um post scriptum. No original manuscrito, havia, encerrando a carta, a seguinte frase: "Quem foi que me mandou um abraço em post-scriptum? Noemia?" (MLb 3.1.00010) Esse post scriptum desaparece na versão publicada em 1969. Novamente, aqui, a hipótese de uma objeção da irmã de Purezinha em ver seu nome estampado no livro parece ganhar força.

Vejamos outra carta, sem data (registrada no livro como tendo sido escrita em Taubaté no ano de 1906):

Minha adorada Purezinha, meu Amor, minha Vida, minha Alegria, minha Esperança, meu Futuro, meu Tudo!

Acabo de receber a tua $3^{\text {a }}$ cartinha (infelizmente este diminutivo é verdadeiro!) e louco de contentamento agarro na pena para a responder, porque escrever-te é o único meio que procuro de prolongar o prazer de te ler. Imagine, minha adorada açucena, que quando ouvi, cá de cima, o carteiro enfiar a correspondência por baixo da porta (é um chiiii que me faz todos os dias pular o coração) larguei do que fazia e corri a ver se havia carta de você. Havia, juntamente com um cartão da Dulce e outro da Stella, dando-me parabéns do noivado. Que alegria! que satisfação! como a alma se me ficou leve! E sabes o que eu fazia nesse momento? Escrevia a acusação que vou pronunciar hoje no tribunal contra os irmãos Patrício. Vê que transição repentina e imensa; saí do crime (Parênteses necessário: estava neste ponto quando entrou-me cá o Davidzinho e me caceteou 5 minutos com umas histórias de dormir em pé, e um cigarro muito fedido), para entrar em plena região da ternura! Deixei dois assassinos para vir palestrar com esse lírio de candura e bondade que és tu!... Então já sonhas comigo? bom sinal! Há em tua carta um pedacinho contra o qual protesto veementemente. "Sonhas sempre que te 
apareço feia (na realidade o sou) e indiferente." O que eu disse foi fria; concordas, ainda, agora, que na realidade o és? Fria, fria, f-r-i-a, nunca feia, porque seria absurdo chamar feio ao que é lindo. Purezinha, estou te rabiscando esta muito às pressas porque são 9 horas, a minha acusação inda não está pronta e às 11 começa a festa; tenho duas h para concluí-la, almoçar e vestir-me. Não fosse isso e enchia o papel até o fim como é meu prazer e teu horror. O julgamento hoje vai até tarde e não mais tenho tempo de pegar na pena e alcançar o correio. Adeus, abraça-te mil vezes e dá-te um milhão de beijos o teu do fundo d'alma sempre e sempre

Juca

[neste ponto, um pedaço do papel, que abrange três linhas, foi recortadd]

Purezinha. Não tenho coragem de largar esta, que é largar-te... Queres-me muito bem? Dize-mo não sejas má, dize-o. Tens-me Amor? Não creio, nem uma só vez tocaste em semelhante palavra. Mas adeus, já deu 9 e 15 min.

[escrito de cabeça para baixo na última página, com tinta de cor azul]

Devolve-ma e o cartão da Dulce (MLb 3.1.00012)

O manuscrito sofreu uma mutilação, um meticuloso corte de um pedaço do papel - fato que não vem registrado na publicação em livro. Mas não apenas o papel, não apenas o suporte material sofreu intervenções: também a transcrição da carta para a publicação em Cartas de amor sofreria uma censura. O imperativo final, em que o remetente pede a devolução da carta e de um cartão de uma certa Dulce - uma possível rival de Purezinha ao coração do jovem Lobato, talvez? - desapareceram na edição das cartas em 1969.

Diante de tudo isso, podemos acreditar na categórica afirmação da organizadora de que "pela primeira vez terá o leitor a oportunidade de ler as cartas de Lobato exatamente como ele as escreveu"?

\section{Ut pictura poesis, ut poesis pictura?}

Mas não apenas de alterações e omissões de palavras ou trechos padece a edição das Cartas de amor. Como se sabe, Lobato também era desenhista - há trabalhos seus publicados em revistas como Fon-Fon - e pintor - o CEDAE recebeu, entre as doações da família de Monteiro Lobato, várias de suas aquarelas. Aliás, é mais do que conhecida a nota biográfica que ilustra sua juventude: a de que Lobato pretendia seguir a carreira das Artes Plásticas, no que foi contrariado pelo avô, o Visconde de Tremembé, que queria - e conseguiu - ver o neto advogado. Mas a veia pictórica de Lobato não deixava de se manifestar em sua correspondência.

Nesse sentido, uma carta bastante interessante é a seguinte, sem data, mas possivelmente do ano de 1906, se confiarmos na informação extraída das Cartas de amor. Há no manuscrito original dois pequenos "enigmas" em francês, que misturam abreviaturas e desenhos, e que, quando da publicação em livro, foram simplesmente omitidos, e sequer mencionados, nem mesmo em nota explicativa. Os "enigmas" querem dizer: "Ne me souris tu encore?", ou seja, "tu não me sorris ainda?”, e "Ne me souris tu toujours?”, em português, "tu não me sorris sempre?" Eles brincam com a homofonia de "souris" em 
francês, que pode ser tanto o substantivo "camundongo" quanto a $2^{\mathrm{a}}$ pessoa do singular do verbo sourir (sorrir). Vejamos a carta:

Pureza

[Ne me souris tu encore?]

A distância apaga o amor; 150 quilôm. não é brincadeira - estando eu tão longe de ti gostarás ainda de mim? Inda habito na casinha da tua memória? Que saudades, Purezinha, tenho... não do passado mas do futuro. Já notou você que se pode ter saudades também do futuro? Tenho saudades da nossa vidinha de casados, metidos numa casa que seja um ninho onde nós ambos cultivaremos, rindo, a planta da felicidade...

[Ne me souris tu toujours?]

Havemos de ter no quintal uma árvore grande cheia de orquídeas, com uma mesinha embaixo e duas cadeiras de balanço. Às tardes calmosas aí iremos depois do jantar, esperar o café - você vestida de um quimono japonês, eu de dólmã branco - conversar, recordar, ouvir Noêmia ripinicar o bandolim. É dessas coisas, Purezinha, que eu tenho saudades, muito mais do que tudo que já se passou. E tu? também não anseias por esse tempo feliz?

Os nossos hóspedes continuam cá, diminuídos porém do Jorge e da Chiquita; quer isto dizer que cá está somente a Santinha. Tem havido muita cousa braba neste apalermado Taubaté; a mais importante foi o aparecimento de um pasquim nojento contra o Afonso, atribuído pelo povo ao Américo Marcato. Em consequência disso, o Joanito "quebrou-lhe a cara" na rua e o patife, que vivia arrotando valentias, nada melhor achou a fazer que aprontar as malas e rodas para Guaratinguetá, sem nem sequer despedir-se da pobre Catarina que está por dias. Eis aí, Pureza, o fato sensacional da semana, discutido e comentado intra e extra-domus, desde a padaria do Adelino até a mesa de jantar do High. Em Taubaté há escassez de fatos sensacionais de modo que quando surge um, o povo gruda-se a ele de unhas e dentes e só o larga quando o mísero decai à vulgaridade da carne de vaca. Temos também uma companhia de operetas, da G. Montani ${ }^{3}$ e Assis Pacheco ${ }^{4}$. Enchentes à Cunha! Fui com as manas e senti aperto n'alma ao ver vazio de ti o camarote que nele uma vez te vi ocupando - pálida e loira, muito loira e fria... para mim só

Ainda há muitas outras novidades, mas chamam-me para almoçar. És servida de almoçar conosco? És servida de almoçar ao lado do teu Juca do coração? (MLb 3.1.00006)



Primeira folha da carta em que se leem os "enigmas" em francês (MLb 3.1.00006 cx1, Fundo Monteiro Lobato - CEDAE - IEL-UNICAMP) 
Tu ainda me sorris? Tu sempre me sorris? A presença de tais jogos, entremeados no discurso amoroso da carta, atenua o tom melancólico do início, vazado pelas saudades que o noivo Monteiro Lobato sente de sua Purezinha. Omitidos, contudo, na publicação da carta em livro (sem, repita-se, qualquer referência à sua existência), a carta passa a soar muito mais melancólica do que realmente o é. Ademais, vemos aqui uma forte demonstração da confluência de linguagens verbais e não-verbais, de que Lobato frequentemente lançava mão em sua correspondência. Um outro exemplo desse procedimento é a carta a seguir, enviada de Areias e datada de 02 de abril de 1907:

Areias, 2.4.07

Minha adorada noivinha

O correio chega às 4 horas nas costas de um burrinho; às $4 \frac{1}{2}$ principia a distribuição e como não há carteiros cada um vai chegando e tomando lugar na agência; o agente, um velho de óculos, Seu Eugênio de Moraes, lê, então, os sobrescritos:

- Sr. Dr. Promotor

- Presente!

Com que febre estendi a mão para as duas únicas cartas que o agente me apresentou. Uma era do Eugênio, a outra... Purezinha, se em Taubaté as tuas cartas me eram um grande prazer aqui são o único grande prazer que posso ter. Li-a na rua e reli-a em casa e neste momento, à medida que vou escrevendo, choco-a de instante em instante com o olhar saudoso. Aspiro o leve perfume que a aromatiza e esse perfume me penetra o olfato da alma e fala-lhe de ti eloquentemente. Que mundo, uma cartinha tua! Que prodígio, esse, de uma simples folha de papel cheia de caracteres ortográficos enebriar os sentidos, embriagar a alma, falar aos olhos, ao olfato, ao espírito, reavivar a Saudade, vitalizar a Esperança! Tanto consegue o Amor!

Sábado tivemos o animado baile que foi uma surpresa. As moças dançaram todas com perfeição. Há uma, Amalie Sampaio, que é a flor da cidade e um silfo na dança. O baile foi nosso, meu e do Carlos de Barros Monteiro delegado. Dançamos com todas elas uma por uma, dissemos-lhes os enganamentos do estilo e demos um sortão. Da minha parte confesso que o devo exclusivamente a ti que me ensinaste a dançar. Houve brinquedo de adivinhação; duas sortes, uma dele, outra minha. Não calculas a nossa cotação. Somos figuras importantíssimas e acatadíssimas. Moramos juntos num grande sobrado com mais dois excelentes rapazes fluminenses que têm loja de fazenda aqui, Samuel e Ismael Miller. Uma verdadeira república que tem estado constantemente cheia de visitantes. Inda há pouco cá se achavam reunidos o Comendador Júlio Sampaio, chefe político, o Sr. J. M. Carvalho, a $1^{\text {a }}$ fortuna do lugar, um professor público e o Comendador Marques um hoteleiro.

Outras vezes reunimo-nos à noite em casa do Dr. Hermógenes, o juiz de $\mathrm{D}^{\circ}$. um distintíssimo moço que é adorado no lugar. A sociedade é restrita mas bem boazinha. Casado, eu teria a coragem de morar aqui. Mas como estou, arcando com o peso das saudades de minha adorada Purezinha é impossível. O pico do Itatiaia fica muito perto daqui de modo que já projetei e está em caminho de realização uma subida às Agulhas Negras ponto culminante do Brasil. Há lá neves eternas... Vê só que delícia não será esse passeio. Infelizmente fá-lo-ei sem você, mas nem que cá estivesses não serias companheira para ele. És tão mimosa para andar... A ladeira de Santo Amaro cansa-te tanto... Tinhas a coragem de subir a 3.000 metros acima do nível do mar? Adeus meu adorado bem, escreve-me o maior número de vezes que puderes; lembra-te que são tuas cartas tudo para mim e que as espero e as leio ansiosa e febrilmente. Um milhão de abraços e beijos do teu, só teu, sempre teu 
[desenho na quarta e última página da carta da cidade de Areias, com as seguintes legendas: à esquerdaPADARIA DO POVO / chafariz / Praça em declive, gramada; à direita-Judas / O que se vê duma janela da minha sala. De cabeça para baixo, o desenho de um rosto, com a seguinte legenda: (Comdor. Sampaio)] (MLb 3.1.00031)

Toda a última página da carta foi tomada por uma série de desenhos, por meio dos quais Lobato pretendia dar à noiva uma amostra do que via na cidade a que acabava de chegar para exercer as funções de promotor público. É, aliás, justamente no exercício dessas funções que redige a carta seguinte, escrita de Areias e datada de 09 de setembro de 1907:

Areias 9.9.07

Purezinha

A calma e monótona Areias pôs ontem as mangas de fora. Imagina tu que ao meio dia recebo notícia que o Comandante do destacamento local, um moço muito bem educado e distinto, fora encontrado na estrada de Queluz, morto, com a boca cheia de sangue. O delegado não estava, o subdelegado estava na roça, de modo que eu tive de tomar as providências necessárias. Logo depois apareceu o carcereiro com notícia que o preso Isaías (o tal velho de que já te falei) enlouquecera. Fui vê-lo. Tinha passado a noite despedaçando as roupas e gritando que o iam fuzilar. Encontrei-o calmo, de pé próximo à grade, com o queixo na mão. Interroguei-o; respondeu estou'maginando - e as lágrimas começaram a correr. Como um louco não chora, deixei-o, convencido de que fora um acesso passageiro, de desespero. Depois soube que mandara chamar a mulher e a filha e lhes pedira perdão. E nada mais houve durante o dia. À meia noite, porém, bateram à nossa porta; fui à janela e divisei dois vultos que me procuravam, o carcereiro e um soldado. - Sr. Dr. vim lhe participar que o Isaías enforcou-se na grade, disse o carcereiro. Chovia, estava de breu a noite, clareada, porém, de longe, por um relampaguear arroxado. Vesti-me e saí. Um quadro lúgubre encontrei. O velho pendurado [há um desenho de Lobato no manuscrito] na grade pelo pescoço, os pés amarrados com um lenço e enfiados por um vão, na atitude de quem está assentado no ar. A língua negra escapava da boca e um fio de baba descia do nariz até o chão. Enforcara-se com a ceroula e tinha atrás da orelha um cigarro de palha que o filho lhe dera durante o dia. Dei ordem para que fossem chamar o delegado muito cedo e vim deitar-me. Pouco depois, a mulher e a filha, avisadas, compareceram e houve cenas de desespero; a filha, porém, permaneceu impassível; não pronunciou uma palavra nem fez um gesto. De manhã, o filho do enforcado que é soldado aqui, apresentou-se com sintomas de loucura e foi mister metê-lo no xadrez onde está berrando como um possesso. Como vês não podia ser mais trágico o dia de ontem. Felizmente não sou nervoso, nem muito impressionável e dormi como um justo após a lúgubre visão, sem sonhos nem pesadelos. Recebi o teu cartão do dia 6 e hoje, segunda, aguardo a carta nele prometida.

Acabo de receber a tua de 8. Que contraste com a minha! Aí festas; aqui tragédias... Mas que me importa isso? Tu és a única realidade para mim. Tudo mais é sonho, é pó. Aí, para mim, há sempre festa, porque minha festa és tu, meu coquetel és tu, meu garden-party és tu. Aqui é sempre triste e trágico - porque tristeza e tragédia querem dizer a tua ausência. Mas não faz mal, havemos de tirar uma desforra e quanto mais demorada for a espera mais intensa será nossa felicidade. Amo-te sempre e cada vez mais; cada dia que se passa sinto fazer progressos o meu amor; ele é como a árvore plantada em terra fértil-cresce sempre, cresce indefinidamente. Adeus, um milhão de abraços, beijos e saudades do teu

Juca (MLb 3.1.00068) 
No meio da carta, Lobato insere um desenho que, ao lado das palavras, reforça a crua imagem do homem enforcado nas grades do cárcere: é esse "quadro lúgubre" que o remetente procura, em seu desenho, esboçar para sua destinatária.

O mesmo procedimento é adotado no topo da primeira página do manuscrito de uma carta escrita de Areias e datada de 12 de novembro de 1907:

[há um desenho de um casarão, provavelmente o mesmo a que se refere Lobato na cartd]

Areias, 12.11.07

Purezinha

Para distrair-nos veio uma semana inteira de chuva e ao tédio normal do meu exílio se juntou o tédio do tempo. Que dias longos, inúteis, difíceis de passar... Felizmente que o luar ontem e o sol hoje mudaram o cenário do mundo e já a vida desentorpece e alegra-se.

Mudei-me de casa. Estou no Humaitá, um casarão patriarcal pertencente aos Lemes no qual também está situada a agência do correio. A metade da casa é minha, a metade é do correio. Mas que casarão! Perco-me dentro dele. Às 6 h. o agente fecha a sua sala e raspa-se. Fico eu só. E como nela morreu, suicidando-se, há 4 anos o pai do Quinzinho, Major Enéas e inda existe no assoalho dum dos quartos manchas de sangue, o povo admira-se, pasma de eu cá dormir sozinho. Mudei-me também de pensão. Estou comendo em casa duma família que mora quase defronte, casa dum maestro, Rodolfo Castro. E só, sem que nada me importune consagro todo o meu tempo às duas cousas que em Areias me tem enchido a vida: pensar em minha Purezinha e ler meus pobres livros. Você ganhou imenso com a mudança. Menos interrompido, menos perturbado, na nova morada penso mais em ti, adoro-te mais em pensamento que na antiga, onde as cantarolas da cozinheira de contínuo me tiravam de você para me pôr na indignação, na zanga. E tu, mazinha, inda... Não! não! vai-te besouro!... Chega de dizer cousas que de leve possam entristecer a minha adorada Purezinha.

Abraça-te e beija-te em plena boquinha o teu eterno

Juca (MLb 3.1.00101)

Parece não bastar a Lobato a descrição em palavras da nova residência, por mais minuciosa que seja. É preciso descrevê-la pictoricamente, é preciso esboçá-la, é preciso compartilhar com a noiva o que seus olhos vêem, como se os olhos dele fossem os dela.

Uma última carta: é a escrita na Bocaina, no início do ano de 1908, portanto a poucos meses do casamento, que ocorreria a 28 de março desse mesmo ano. Lobato estava numa fazenda que costumava visitar regularmente. Vejamos a carta:

Bocaina, Invernada do Pinhal

Purezinha

Por mais que dês largas à tua imaginação não suspeitarás onde estou e como te escrevo. Estou sozinho numa invernada, a 50 braças da casa do campeiro, eu, aqui, ele lá, e só, em 500 alqueires de campo. Estou sentado à porta, tendo em minha frente a morraria linda, os pinheiros, a mata, e uma 


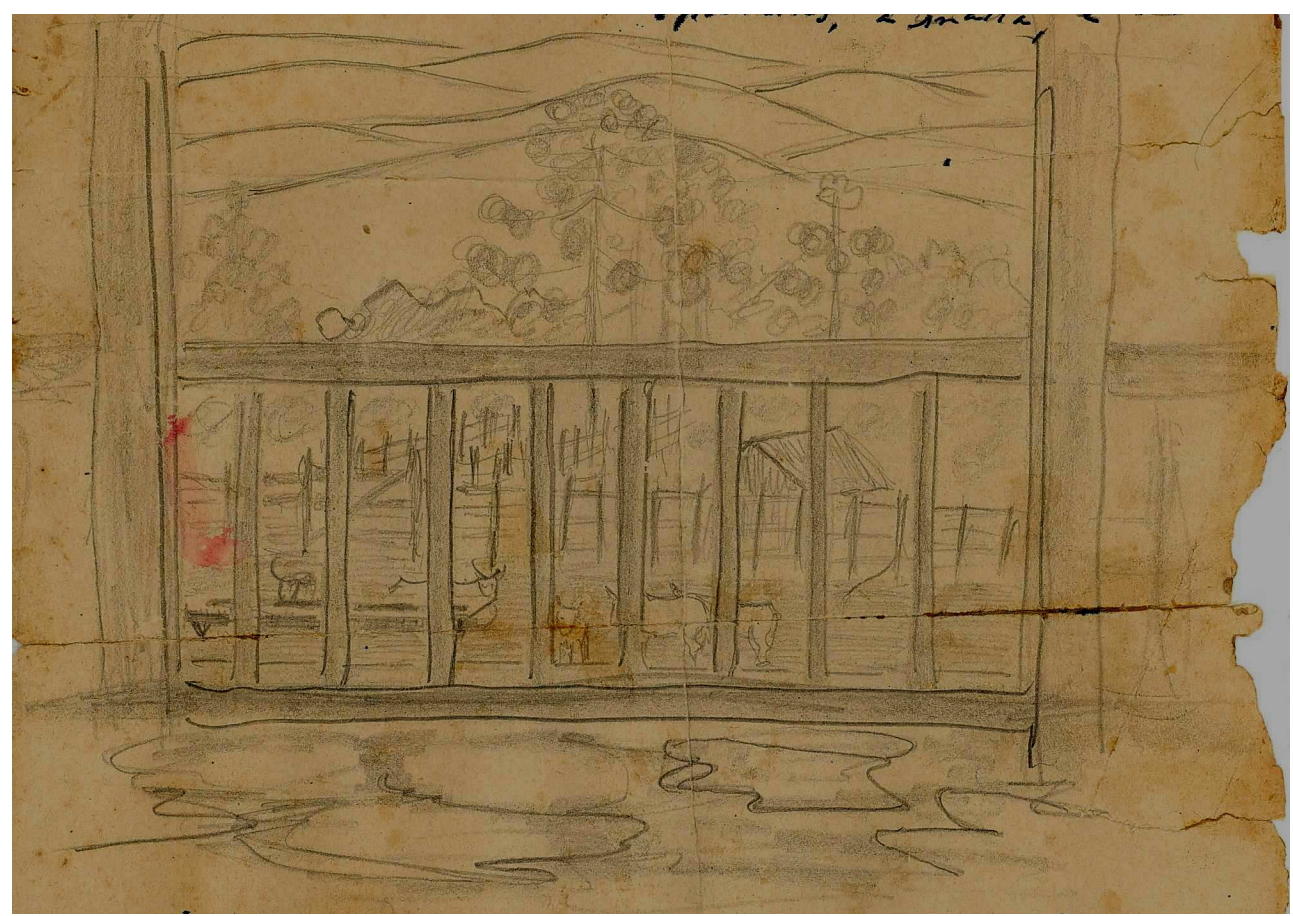

mangueira com meia dúzia de reses dentro. Na frente da casa há uma varanda e a grade dessa varanda é o que vês no esboço acima; a mangueira e o gado vê-se por detrás da grade. A solidão e o silêncio são completos. Só o bem-te-vi e, de raro em raro o gavião quebram o silêncio magnífico. Também o vento às vezes, farfalhando os pinheiros. O meu companheiro, o Baroni, foi logo depois do almoço e fiquei só. Jantei com colher de estanho emprestada pelo campeiro. Há pêssegos como nunca vi em tamanha quantidade. As árvores, derreadas, deitam para o chão os galhos apinhados. E nem um bicho para remédio. Não fosse a grande distância que nos separa e te mandaria um cargueiro. Mas é muito ir daqui do Orizaba a Areias, de Areias a Queluz, de Queluz a S. Paulo, fica muito comprido. Encontrei uns velhos livros que me têm feito companhia. Entre eles estão Platão (por estas alturas!) em suas obras completas, e Nicolau Tolentino - esse horrível lamuriento.

Chove. É horrível a chuva aqui, produz uma tristeza imensa, sem nome. Perdi o dia, não pude fazer nada por causa dela. Vamos ver amanhã.

Uma vaca berrou longe. Triste... Como escurece os grilos da noite já começam a chiar. Há um grilo que é peculiar destas regiões; canta como um diapasão de piano em falso, tremido. Encontrei-me com 3 cobras e como ia a cavalo pus-me a observá-las e acompanhá-las pelo meio do campo. É um animal lindo assim, pilhado em flagrante; por uma cobra morta não se pode imaginar a graça, a elegância dos coleios de uma com vida. Vem chegando mais vacas para o curral, mugindo. Uma queimada parou na porteira para se coçar no mancarrão. Penso constantemente em você, posso mesmo dizer que não estou só, tanto me fazes companhia, tanto a imaginação trabalha em figurar a realidade. Quantas intermináveis palestras travo contigo. Tudo que vejo de novo te mostro, te conto, te explico. Já na vinda figurei que vinhas ao meu lado e te ia contando tudo - aquele fica lá, é o Boa Vista, este aqui os Burrinhos - Esse passarinho que cantou é o soldado - aquela árvore é o cambuí - and so far.

Adeus, Purezinha e recebe o abraço do

que nunca, nem um só instante

te esquece 
[no verso da última folha, capa do “Catálogo']

Não há tinta nem papel aqui. Felizmente eu tive a ideia de trazer envelopes já sobrescritados e selados. (MLb 3.1.00152)

Não encontrando nem papel, nem tinta - a carta havia sido escrita primeiramente a lápis e foi posteriormente preenchida por cima a tinta - para escrevê-la, Lobato utilizou-se da capa e página de índice de um catálogo de partituras. Mas não é só. O remetente abre a carta, após um vocativo simples, interrogando a destinatária sobre o lugar de onde escreve. Passa, então, a descrever todo o cenário à sua volta. Não contente com isso - e provavelmente considerando a carta um veículo insuficiente para descrever e demonstrar tudo o que via e queria -, Lobato inclui um desenho no meio da carta, entre as expressões "a mangueira" e "e o gado", desenho que retrata a visão que tinha a partir do lugar de onde escrevia.

\section{Considerações finais}

Todos esses desenhos de Lobato, inseridos no meio de suas cartas, não constituem mera ilustração, não são simplesmente desenhos a embelezar a correspondência. Podemos ver aqui o fenômeno de presentificação dos correspondentes por meio da carta. Como afirma Luiz Felipe Baêta Neves, a carta é a presença de uma ausência. A carta, tradicionalmente (funcionalmente), é vista apenas
como uma forma de comunicação. Mas, ela pode comunicar uma falta, uma distância. Em
princípio, o destinatário não está presente; a carta é, assim, a reiteração de um afastamento
(NEVES, 1988, 191)

Ora, se a carta torna presentes os ausentes, se remetente e destinatário encontram-se por meio da carta, o que é visto pelo remetente não seria visto também pelo destinatário? Se esse argumento é aceitável, certamente com mais força o será no contexto de uma relação amorosa, em que os apaixonados entregam-se um ao outro em cada linha da correspondência. No caso específico de Lobato, porém, esse fenômeno da presentificação dos apaixonados por meio da carta adquire outra dimensão, justamente nesse diálogo estabelecido entre o texto e a imagem. De algum modo, pode-se lembrar aqui a observação de Marisa Lajolo a respeito dos cartões-postais do escritor:

Também no traçado caprichoso das letras, desenhadas de forma a comporem um todo harmonioso [...], podemos encontrar o artista plástico de gosto requintado [...]. Assim, nas mãos de um correspondente tão íntimo da palavra escrita como Monteiro Lobato, vemos que o gesto de escrever pode sempre ser uma forma de criação, ainda que em espaços apertados e convencionais como um cartão-postal. (LOBATO, 2006, 19)

Talvez seja nessa íntima interação entre texto e imagem que possamos entender como Lobato, por meio da correspondência, alimentava a relação amorosa com a noiva, ao mesmo tempo em que com ela reforçava, pouco a pouco, a cumplicidade, já que, 
lembrando as palavras de Mário Sette, não poderiam se expandir verbalmente e tiveram que arranjar um jeito de estabelecer uma correspondência escrita.

Tudo isso, porém, ficou oculto aos olhos dos leitores por mais de três décadas, desde a publicação das cartas em 1969 até a incorporação dos documentos, após a doação da família de Monteiro Lobato, ao acervo do CEDAE. A presença desses documentos num centro de documentação com acesso franqueado ao público permite, assim, restaurar a leitura original dessas cartas, desfazendo equívocos e possibilitando aos pesquisadores a formulação de novas hipóteses de trabalho e de pesquisa.

\section{Notas}

${ }^{1}$ A história da chegada do acervo e de sua incorporação ao CEDAE foi minuciosamente reconstruída por Marisa Lajolo em seu ensaio intitulado "Um tesouro de papéis" (LOBATO, 2006, 6-11).

${ }^{2}$ Essa numeração, bem como a de exemplos subsequentes, refere-se ao registro das cartas no CEDAE / IEL / UNICAMP.

${ }^{3}$ Trata-se, possivelmente, da atriz Gabriella Montani (1854-1926).

${ }^{4}$ Possivelmente, Francisco de Assis Pacheco (1865-1937), compositor e regente brasileiro. Para sua biografia, consulte-se o Dicionário Cravo Albin da Música Popular Brasileira. Disponível em: http:// www.dicionariompb.com.br/verbete.asp?tabela=T_FORM_A\&nome=Assis+Pacheco Acesso em: 15 dez. 2008.

\section{Bibliografia}

DICIONÁRIO CRAVO ALBIN DA MÚSICA POPULAR BRASILEIRA. Disponível em: http:// www.dicionariompb.com.br/verbete.asp?tabela=T_FORM_A\&nome=Assis+Pacheco Acesso em: $15 \mathrm{dez} .2008$.

LOBATO, Monteiro. Cartas a Purezinha. Manuscritos originais depositados no Fundo Monteiro Lobato do Centro de Documentação Cultural Alexandre Eulálio. Campinas: IEL/UNICAMP (MLb 3.1.00006, MLb 3.1.00010, MLb 3.1.00012, MLb 3.1.00031, MLb 3.1.00068, MLb 3.1.00101, MLb 3.1.00152). . Cartas de amor. Prefácio, compilação e notas de Cordélia Fontainha Seta. São Paulo: Brasiliense, 1969. - Quando o carteiro chegou... Cartões-postais a Purezinha. Organização e apresentação de Marisa Lajolo. Transcrição e notas de Emerson Tin. São Paulo: Moderna, 2006.

NEVES, Luiz Felipe Baeta. Para uma teoria da carta - Notas de pesquisa. In: As máscaras da totalidade totalitária - Memória e produção sociais. Rio de Janeiro: Forense Universitária, 1988, pp.191-195.

SETA, Cordélia Fontainha. Prefácio. In: LOBATO, Monteiro. Cartas de amor. Prefácio, compilação e notas de Cordélia Fontainha Seta. São Paulo: Brasiliense, 1969, pp.IX-XI.

SETTE, Mário. Memórias intimas: caminhos de um coração. Recife: Fundação de Cultura Cidade do Recife, 1980. 
